\title{
Quality assessment of Moringa concanensis seed oil extracted through solvent and aqueous-enzymatic techniques
}

\author{
By Sajid Latif and Farooq Anwar*
}

\author{
Department of Chemistry, University of Agriculture, \\ Faisalabad-38040, Pakistan \\ Corresponding author: fqanwar@yahoo.com
}

\section{RESUMEN}

Evaluación de la calidad del aceite de semilla de Moringa concanensis extraído mediante disolvente y adición de enzimas.

En este estudio se compara la composición y la calidad del aceite de semilla de $M$. concanensis extraído mediante enzimas, utilizando tres enzimas comerciales (Natuzyme, Kemzyme, y Feedzyme) con las de un control extraído sin enzimas y con las del aceite extraído con disolvente. El contenido en aceites de las semilla extraídas con enzimas osciló entre 23,54 a $27,46 \%$ y fue significativamente más elevado $(P<0.05)$ que el del control sin enzimas $(15.41 \%)$. Los análisis de los residuos (harinas) no mostraron diferencias significativas $(P>0,05)$ en el contenido de fibra y ceniza para los tres métodos de la extracción. Sin embargo, el contenido proteínico de la harina obtenido por métodos enzimáticos y el control sin enzimas fue significativamente menor $(P<0,05)$ que el de la harina obtenida después de la extracción por disolvente. Las diferencias en el índice de yodo (67.1-68.0 g / $100 \mathrm{~g}$ of oil), densidad en $24{ }^{\circ} \mathrm{C}(0,865-0,866$ $\mathrm{g} / \mathrm{mL})$, índice de refracción a $40{ }^{\circ} \mathrm{C}(1,4622-1,4627)$ y fracción insaponificable $(0,69-0,76 \%)$ no fueron significativamente diferentes para ninguna de las técnicas de extracción. Las extinciones específicas en 232 y $270 \mathrm{~nm}$, el índice de peróxidos, el índice de p-anisidina, la acidez libre y el color de los aceites extraídos con enzimas fueron inferiores a los del aceite obtenido mediante extracción con disolvente. La composición en ácidos grasos de los aceites fue similar en todas los aceites encontrándose sólo pequeñas en los contenidos de ácido esteárico y linoleico. Respecto a los tocoferoles, el contenido en g-tocoferol fue similar en el control y en las extracciones con enzimas y significativamente más elevado $(P<0.05)$ que en el aceite extraído con disolvente, mientras que el contenido en a-tocoferol fue superior en el aceite extraído con disolvente.

PALABRAS-CLAVE: Aceite de Moringa concanensis Acidos grasos - Características físico-químicas - Enzimas Métodos de extracción - Tocoferoles.

\section{SUMMARY}

Quality assessment of Moringa concanensis seed oil extracted through solvent and aqueous-enzymatic techniques.

The composition and quality of the M. concanensis seed oil extracted through an aqueous-enzyme-assisted technique, using three commercial enzyme-mixtures (Natuzyme, Kemzyme, and Feedzyme) was compared to those of the control-, (without enzymes) and solvent-extracted oils. Aqueous enzyme-extracted M.concanensis seed oil content ranged from 23.54 to $27.46 \%$ and was significantly $(P<0.05)$ higher than that of the control $(15.41 \%)$. Analyses of the oilseed residues (meals) revealed no significant $(P>0.05)$ variation in the contents of fiber and ash within the three extraction methods. However, the protein content of the meal obtained through the aqueous-enzyme and control methods was significantly $(P>0.05)$ lower as compared to that of the solvent-extracted. There were no significant $(P>0.05)$ differences in iodine value $(67.1-68.0 \mathrm{~g}$ of iodine $/ 100 \mathrm{~g}$ of oil), density at $24^{\circ} \mathrm{C}\left(0.865-0.866 \mathrm{~g} \mathrm{~mL}^{-1}\right)$, refractive index at $40{ }^{\circ} \mathrm{C}(1.4622-1.4627)$ and unsaponifibale $(0.69-0.76 \%)$ matter of the $M$. concanensis seed oils extracted using the three methods. The specific extinctions at 232 and $270 \mathrm{~nm}$, peroxide value, $p$-anisidine, free fatty acid contents and color values of the aqueous-enzyme-extracted oil were found to be lower than that of solvent-extracted oil and thus revealed good quality. The oils extracted through the three methods exhibited no significant $(P>0.05)$ variation in their contents of major fatty acids except stearic (18:0) and linoleic (18:2) acids. The level of $\gamma$-tocopherol in enzymeextracted oil, even though comparable to the control, was significantly $(P<0.05)$ higher than that of solvent-extracted oil. The content of $\alpha$-tocopherol in the enzyme-extracted oil was found to be higher than that of the control but lower than that of solvent- extracted oil.

KEY-WORDS: Enzyme-assisted aqueous - Extraction methods - Fatty acids - Moringa concanensis oil - Oxidative stability - Physico-chemical characteristics - Tocopherols

\section{INTRODUCTION}

Moringaceae, a monogeneric family, belonging to the genus Moringa is characterized by a number of species such as Moringa peregrine (M.peregrina), M.oleifera, M.arabica M.stenopetala M. concanensis, M. ovalifolia M. hildebrantii, M. arborea, Moringa rivae and Moringa ruspoliana etc. (Tsaknis et al., 1999; Olson, 2003; Aregheore 2002). Almost all Moringa species, native to India are now distributed in many tropical and sub-tropical parts of the world like India, Pakistan, Asia Minor, Africa and Arabia (Mughal et al., 1999, Anwar and Bhanger 2003).

The Moringa plant is well-regarded as an important food commodity equipped with high-value nutritious properties (Anwar et al., 2007). Different parts of this plant: root, bark, gum, leaf, fruit (pods), flowers, seed and seed oil have been used for 
various ailments in the indigenous medicine practices of South Asia, which included the cure of inflammation, cardiovascular, gastrointestinal, hematological and hepatorenal disorders (Singh et al., 1999; Morimitsu et al., 2000; Siddhuraju and Becker, 2003). The seeds of the Moringa are considered to exhibit antipyretic and antimicrobial activities, used for water purifying and are also a good source of non-desiccating oil, commercially known as 'Ben oil' (Anwar et al., 2007).

In Pakistan Moringa is characterized by two species; Moringa oleifera (M.oleifera) and $M$. concanensis (M.concanensis). The former is widely cultivated across the country; however, the latter is rarely found and only confined to a remote area of Tharparkar, Sindh (Manzoor et al., 2007, Anwar 2003). The species, Moringa concanensis has recently been characterized with regard to its seed oil potential. Its oil is high in oleic acid and resembles in context of fatty acid composition with seed oils of other Moringa species, which includes the $M$. stenopetala, $M$. peregrina and $M$. oleifera (Manzoor et al., 2007). High-oleic oils are gaining importance, especially for replacing polyunsaturated vegetable oils (Corbett, 2003) and are reported to exhibit good oxidative stability during frying (Anwar et al., 2007).

Conventionally, $n$-hexane is used as a solvent for the extraction of oils from vegetable oil seeds. However, the environmental problems, safety issues and health concerns have prompted the need to find some environmentally-friendly alternatives to hexane (Bhattacharjee et al., 2006). The U.S. Environmental Protection Agency provided incentives for developing alternative methods of edible oil extraction and guidelines for hexane emissions by vegetable oil extraction sources (EPA, 2001). The new tendency to avoid the use of toxic organic solvents in large installations has renewed interest in alternative extraction processes (involving the use of water, alcohol aqueous solutions and supercritical fluids) (Johnson and Lusas, 1983).

A number of aqueous (Rhee et al., 1972; Shi et al., 1998), and aqueous enzymatic extraction (Hanmoungjai et al., 2001; Rosenthal et al., 1996; Rosenthal et al., 2001; Sharma et al., 2002) methods have been developed for the extraction of oil seeds. Shi et al. (1998), reported an aqueous method that resulted in an $80 \%$ yield of peanut oil from peanuts. Karlovic et al. (1994) investigated an aqueous enzymatic method for the extraction of corn germs using cellulase which resulted in $80 \%$ oil yield.

The main purpose of using the enzymes during aqueous oil extraction is to hydrolyze the structural polysaccharides which form the cell wall of oilseeds or the proteins which form the cell and lipid body membrane. The aqueous enzyme-assisted extraction process removes phospholipids from the oil so that there is no need for degumming, thereby, reducing the overall cost of processing of the oil to the final product (Christensen, 1991). The major disadvantage of using enzymes for oil seed extraction, although safer, is that they are expensive and offer quite lower oil yield as compared to solvent extraction. Nevertheless, the other technical benefits surrounding enzyme-assisted aqueous oil extraction can make this technique viable.

Currently, much effort is being devoted to develop and introduce commercial enzymes for aqueous enzymatic oil extraction. The present work was therefore, an attempt to evaluate the potential of three commercial enzymes for extraction of oil from $M$. concanensis seeds by applying the aqueous enzymatic technique. The physicochemical characteristics of the aqueous enzymeextracted $M$. concanensis seed oil were also compared to that of conventional solvent extracted and control oils.

\section{EXPERIMENTAL}

\subsection{Materials}

The seeds of Moringa concanensis were assayed from the vicinity of Tharparker, Sindh, Pakistan. All reagents (analytical and HPLC) used for analysis were from Merck (Darmstadt, Germany) or Sigma Aldrich (Buchs, Switzerland), unless stated otherwise. Pure standards of tocopherols [DL- $\alpha-$ tocopherol, (+)- $\delta$-tocopherol, $(+)$ - $\gamma$-tocopherol] and FAMEs (fatty acid methyl esters) were obtained from Sigma Chemical Co. (St. Louis, MO). Three commercial enzyme-mixtures: Kemzyme (mainly alpha-amylase, beta-glucanase, cellulase-complex, hemicellulase-complex, protease and xylanase activities), Natuzyme (mainly cellulose, xylanase, phytase, alpha-amylase, pectinase activities), Feedzyme (mainly xylanase beta-glucanase cellulase and hemicellulase activities) were of Kemin Europa N.V., Herentals, Belgium (Vet Pharma Trading Company, Gujranwala, Pakistan); Bioproton Pty Ltd, Brisbane, Australia (M/S Ghazi Brothers, Karachi, Pakistan); and Agil, Reading, England (Better Traders International, Faisalabad, Pakistan), respectively.

\subsection{Oil extraction}

\subsubsection{Aqueous enzyme-assisted extraction}

For aqueous enzyme extraction, ground seeds $(25 \mathrm{~g})$ were mixed with distilled water $(150 \mathrm{ml})$ at a ratio of $1: 6 \mathrm{w} / \mathrm{v}$ for the method followed by Abdulkarim et al. (2005). The mixture was boiled for $5 \mathrm{~min}$ and allowed to cool down to room temperature. The $\mathrm{pH}$ was then adjusted to the optimal $\mathrm{pH}$ for each enzyme with 0.5 $\mathrm{N} \mathrm{NaOH}$ and $0.5 \mathrm{~N} \mathrm{HCl}$. Two percent (w/w) E/S (enzyme/substrate) ratio of each of the three enzymemixtures (Kemzyme, Natuzyme, and Feedzyme) were added and the mixture incubated at $45^{\circ} \mathrm{C}$ for $24 \mathrm{~h}$ with constant shaking at $120 \mathrm{rpm}$. The oil was recovered after centrifugation $\left(8000 \mathrm{rpm}, 20^{\circ} \mathrm{C}\right)$ for 20 minutes using a centrifuge machine (Sigma, 3K 30, Osterode am Harz, Germany) (Abdulkarim et al., 2005). The wet 
meal was mixed and dried overnight in a vacuum oven (VOC-300 SD; EYELA, Tokyo, Japan) at $85-90^{\circ} \mathrm{C}$. The dry meal was ground and analyzed for ash, fiber, and protein contents. The Control samples were also proceeded under the same set of conditions, except enzyme addition.

\subsubsection{Solvent extraction}

After the removal of seed hull and other impurities, the seeds (150 g) were crushed and then fed to a Soxhlet extractor fitted with a $1.0 \mathrm{~L}$ round-bottom flask and a condenser. The extraction was executed on a water bath for $6 \mathrm{~h}$ with $0.5 \mathrm{~L}$ of $n$-hexane. The solvent was distilled off under vacuum in a rotary evaporator (Eyela, N-N Series, Rikakikai Co. Ltd. Tokyo, Japan) at $45^{\circ} \mathrm{C}$. The oil obtained from both extractions was stored under refrigeration $\left(4^{\circ} \mathrm{C}\right)$, until used for further analyses.

\subsection{Analysis of the oilseed residues/ meals}

After oil extraction (both by enzyme and solvent extraction), the meals were analyzed for protein, fiber, and ash contents. Protein content was determined according to the AOAC (1990) method 954.01. Fiber content was estimated according to an ISO (1977) method 5983. A finely ground sample $(2.5 \mathrm{~g})$ of meal was weighed and freed from fat by extraction with $15-\mathrm{mL} n$-hexane. The test portion was boiled with sulfuric acid $\left(0.255 \mathrm{~mol} \mathrm{~L}^{-1}\right)$, followed by separation and washing of the insoluble residue. The residue was then boiled with sodium hydroxide $\left(0.313 \mathrm{~mol} \mathrm{~L}^{-1}\right)$, followed by separation, washing, and drying. The dried residue was weighed and ashed in a muffle furnace (TMF-2100, Eyela, Tokyo, Japan) at $600{ }^{\circ} \mathrm{C}$, and the loss of mass was determined.

Ash content was determined according to an ISO (1977) method 749. Two grams of the test portion were taken and carbonized by heating on a gas flame. The carbonized material was then ashed in an electric muffle furnace (TMF-2100, Eyela, Tokyo, Japan) at $550{ }^{\circ} \mathrm{C}$ until a constant mass was achieved.

\subsection{Analysis of extracted oil}

\subsubsection{Physical and chemical parameters of oil}

lodine value, refractive index, density, unsaponifiable matter, peroxide and saponification values of the enzyme extracted and the control $M$. concanensis seed oils were determined by various standard AOCS (1997) methods. The color of the oil was determined by a Lovibond tintometer (Tintometer Ltd., Salisbury, Wiltshire, United Kingdom) using a 1inch cell. Specific extinctions at 232 and $270 \mathrm{~nm}$ were determined using a spectrophotometer (U-2001, Hitachi Instruments, Inc., Tokyo, Japan). Samples of oil were diluted with iso-octane, and spectra were recorded at 232 and $270 \mathrm{~nm}$, and $\varepsilon^{1 \%}{ }_{1 \mathrm{~cm}}(\lambda)$ calculated following the standard IUPAC (1987) method. para-Anisidine values were also determined following an IUPAC (1987) method.

\subsubsection{Fatty acid (FA) composition}

FAMEs were prepared according to the IUPAC (1987) method 2.301 and were analyzed on a Shimadzu (Kyoto, Japan) gas chromatograph, model 17-A, fitted with a methyl lignocerate coated film thickness $0.20 \mu \mathrm{m})$ SP-2330 polar capillary column (30 $\mathrm{m} \times 0.32 \mathrm{~mm}$; Supelco Inc., Supelco Park Bellefonte, PA), and a flame ionization detector (FID). Oxygen-free nitrogen was used as a carrier gas at a flow rate of $3.0 \mathrm{~mL} \mathrm{~min}^{-1}$. Other conditions were as follows: initial oven temperature, $180{ }^{\circ} \mathrm{C}$; ramp rate, $5{ }^{\circ} \mathrm{C} \min ^{-1}$; final temperature, $220{ }^{\circ} \mathrm{C}$; injector temperature, $230{ }^{\circ} \mathrm{C}$; detector temperature, $250^{\circ} \mathrm{C}$; and temperature hold, 2 min before and 10 min after the run. A sample volume of $1.5 \mu \mathrm{L}$ was injected. FAMEs were identified by comparing their relative and absolute retention times to those of authentic standards. A data-handling program, Chromatography Station for Windows (CSW32), was used for quantification. The FA composition was reported as a relative percentage of the total peak area.

\subsubsection{Tocopherol content}

Tocopherols ( $\alpha, \gamma$, and $\delta$ ) were analyzed using an HPLC following the CPFA (Current Protocols in Food Analytical Chemistry) (Wrolstad, 2003) methods. 0.1 $\mathrm{g}$ oil sample and $0.05 \mathrm{~g}$ ascorbic acid were weighed accurately into a $16 \times 125-\mathrm{mm}$ test tube. Five milliliters of $90.2 \%$ ethanol and $0.5 \mathrm{ml}$ of $80 \%$ aqueous $\mathrm{KOH}$ solution were added to the test tube and vortexed for $30 \mathrm{sec}$. The test tube was flushed with nitrogen, capped and incubated in a water bath $\left(70^{\circ} \mathrm{C}\right)$ for $30 \mathrm{~min}$ with periodical vortexing. The tubes were placed in an ice bath for 5 min then $3 \mathrm{ml}$ deionized water and $5 \mathrm{ml} n$-hexane were added and vortexed for $30 \mathrm{sec}$ followed by centrifugation for 10 $\min$ at $1000 \times g$ (room temperature). The upper hexane layer was transferred to another test tube. The aqueous layer and the residue were re-extracted by repeating the same procedure. The upper hexane layers from both the extractions were combined and evaporated to dryness under nitrogen streaming. One milliliter of mobile phase was added to the tube and vortexed $30 \mathrm{sec}$ to re-dissolve the extract and then transferred to an HPLC sample vial. A 20- $\mu \mathrm{L}$ sample was injected into a Supelcosil LC-Si column $(250 \times 4.6 \mathrm{~mm}$, Supelco Inc., Supelco Park, Bellefonte, USA). A mobile phase of ethyl acetate/acetic acid/hexane (1:1:198, v/v/v) was used at the rate of $1.5 \mathrm{~mL} \mathrm{~min}^{-1}$. Detection was monitored at $295 \mathrm{~nm}$. Tocopherols were identified by comparing their retention times with those of pure standards of $\alpha-, \gamma-$, and $\delta$ - tocopherols, and were quantified on the basis of peak area of the unknowns with those of 
pure standards (Sigma Chemical Co.). Quantification was based on an external standard method. A D2500 Hitachi Instruments, Inc., Tokyo, Japan Chromatointegrator model with a built-in computer program for data handling was used for quantification.

\subsection{Statistical analysis}

Three M. concanensis seed samples for each of the three enzyme treatments were analyzed individually in triplicate. Data were reported as means \pm SD $(n=3 \times 3)$. One way ANOVA was used to determine significant differences between groups, considering a level of significance of less than $5 \%(P<$ 0.05 ) by using the statistical software STATISTICA 5.5 (Stat Soft Inc, Tulsa, Oklahoma, USA).

\section{RESULTS AND DISCUSSION}

The oil content (23.54-27.46\%) of aqueous enzyme-assisted $M$. concanensis seed was significantly $(P<0.05)$ higher than that of the control $(15.41 \%)$, but lower than that extracted with hexane $(38.40 \%)$ (Table 1). The oil concentration was highest $(27.46 \%)$ in the Kemzyme treated seed samples, whereas the seeds treated with Feedzyme afforded the lowest oil content (23.54\%). The increase in oil yield in the present aqueous enzyme-assisted extraction of $M$. concanensis seed as compared to the control might be attributed to the enzyme activity. The multiple activity complexes and enzyme mixtures are especially effective for degradation of seed cell walls, due to their synergistic action thus making more oil available for extraction (Sineiro et al., 1998). The analysis of the meals revealed the protein content (19.06-20.17\%) of the $M$. concanensis seed treated with enzymes to be significantly $(P<0.05)$ lower than that of the control and solvent-extracted seeds. This decrease may be due to the extraction of some protein in the aqueous and the emulsion phases. Fiber and ash contents in the enzyme treated oil seeds ranged from 5.94 to 6.12 , and 6.98 to $7.17 \%$, respectively and were almost comparable to those of the control and solvent-extracted and showed no significant $(P>0.05)$ variations.

Table 2 shows the data for various physicochemical parameters of the enzyme-, solventextracted and the control- $M$. concanensis seed oils. There were no significant $(P>0.05)$ differences in the iodine value (67.1-68.0 $\mathrm{g}$ of iodine $/ 100 \mathrm{~g}$ of oil), density at $24{ }^{\circ} \mathrm{C}\left(0.865-0.866 \mathrm{~g} \mathrm{~mL}^{-1}\right)$, refractive Index at $40{ }^{\circ} \mathrm{C}(1.4622-1.4627)$ and unsaponifiable matter $(0.69-0.71 \%)$ of the $M$. concanensis seed oils extracted through three extraction methods. The saponification (173-175 mg of $\mathrm{KOH} / \mathrm{g}$ ), of the aqueous enzyme-extracted $M$. concanensis seed oil was found to be comparable to the control but

Table 1

Proximate composition of Moringa concanensis seeds ${ }^{A}$

\begin{tabular}{lccccc}
\hline & & \multicolumn{3}{c}{ Enzyme-extracted } & \multirow{2}{*}{ Control } \\
\cline { 3 - 5 } Constituent (\%) & Solvent-extracted & Natuzyme & Kemzyme & Feedzyme & $15.41 \pm 0.28^{\mathrm{d}}$ \\
\hline Oil content & $38.40 \pm 0.97^{\mathrm{a}}$ & $25.34 \pm 0.59^{\mathrm{bc}}$ & $27.46 \pm 0.64^{\mathrm{b}}$ & $23.54 \pm 0.43^{\mathrm{c}}$ & $25.41 \pm 0.84^{\mathrm{b}}$ \\
Protein content & $30.25 \pm 0.86^{\mathrm{a}}$ & $20.17 \pm 1.03^{\mathrm{c}}$ & $19.45 \pm 0.80^{\mathrm{c}}$ & $19.06 \pm 1.05^{\mathrm{c}}$ & $6.10 \pm 0.09^{\mathrm{a}}$ \\
Fiber content & $6.15 \pm 0.12^{\mathrm{a}}$ & $6.09 \pm 0.10^{\mathrm{a}}$ & $6.12 \pm 0.08^{\mathrm{a}}$ & $5.94 \pm 0.11^{\mathrm{a}}$ & $6.10 .10^{\mathrm{a}}$ \\
Ash content & $7.20 \pm 0.11^{\mathrm{a}}$ & $7.17 \pm 0.13^{\mathrm{a}}$ & $6.98 \pm 0.09^{\mathrm{a}}$ & $7.00 \pm 0.12^{\mathrm{a}}$ & $7.12 \pm 0.10^{\mathrm{a}}$ \\
\hline
\end{tabular}

${ }^{A}$ Values are means \pm SD, calculated as percentage on dry seed weight basis for three Moringa concanensis seed samples for each enzyme analyzed individually in triplicate.

Mean values in the same row followed by the same superscript letters are not significantly different $(P>0.05)$.

Table 2

Physico-chemical properties of Moringa concanensis seed oils ${ }^{\mathrm{A}}$

\begin{tabular}{|c|c|c|c|c|c|}
\hline \multirow[b]{2}{*}{ Constituent } & \multirow[b]{2}{*}{ Solvent-extracted } & \multicolumn{3}{|c|}{ Enzyme-extracted } & \multirow[b]{2}{*}{ Control } \\
\hline & & Natuzyme & Kemzyme & Feedzyme & \\
\hline Refractive Index $\left(40^{\circ} \mathrm{C}\right)$ & $1.4644 \pm 0.002^{\mathrm{a}}$ & $1.4627 \pm 0.003^{\mathrm{a}}$ & $1.4625 \pm 0.002^{\mathrm{a}}$ & $1.4622 \pm 0.003^{\mathrm{a}}$ & $1.4624 \pm 0.002^{\mathrm{a}}$ \\
\hline Density $\left(24{ }^{\circ} \mathrm{C} \mathrm{g} / \mathrm{mL}\right)$ & $0.866 \pm 0.04^{\mathrm{a}}$ & $0.866 \pm 0.02^{\mathrm{a}}$ & $0.865 \pm 0.06^{\mathrm{a}}$ & $0.865 \pm 0.01^{\mathrm{a}}$ & $0.865 \pm 0.03^{\mathrm{a}}$ \\
\hline Saponification value (mg KOH/g oil) & $180 \pm 3.43^{\mathrm{a}}$ & $174 \pm 2.59^{a}$ & $175 \pm 4.32^{\mathrm{a}}$ & $173 \pm 3.86^{\mathrm{a}}$ & $176 \pm 4.79^{\mathrm{a}}$ \\
\hline Acidity (\% as oleic acid) & $0.32 \pm 0.01^{\mathrm{a}}$ & $0.19 \pm 0.02^{b}$ & $0.17 \pm 0.02^{b}$ & $0.20 \pm 0.01^{b}$ & $0.18 \pm 0.03^{b}$ \\
\hline lodine value (g of l/ $100 \mathrm{~g}$ oil) & $66.7 \pm 1.28^{\mathrm{a}}$ & $67.6 \pm 1.59^{\mathrm{a}}$ & $68.0 \pm 1.70^{\mathrm{a}}$ & $67.1 \pm 2.15^{\mathrm{a}}$ & $67.2 \pm 1.98^{\mathrm{a}}$ \\
\hline Unsaponifiable matter (\% w/w) & $0.76 \pm 0.02^{\mathrm{a}}$ & $0.71 \pm 0.01^{a}$ & $0.69 \pm 0.02^{\mathrm{a}}$ & $0.70 \pm 0.04^{a}$ & $0.67 \pm 0.03^{\mathrm{a}}$ \\
\hline \multicolumn{6}{|l|}{ Color (1-in. cell) } \\
\hline Red units & $2.1 \mathrm{r} \pm 0.04^{\mathrm{a}}$ & $1.2 r \pm 0.03^{b}$ & $1.3 r \pm 0.05^{b}$ & $1.2 r \pm 0.07^{b}$ & $1.2 r \pm 0.04^{b}$ \\
\hline Yellow units & $19 y \pm 0.38^{a}$ & $14 y \pm 0.43^{b}$ & $14 \mathrm{y} \pm 0.35^{\mathrm{b}}$ & $12 \mathrm{y} \pm 0.51^{\mathrm{c}}$ & $14 y \pm 0.49^{b}$ \\
\hline
\end{tabular}

${ }^{A}$ Values are means \pm SD, of three Moringa concanensis seed oils analyzed individually in triplicate.

Mean values in the same row followed by the same superscript letters are not significantly different $(P>0.05)$. 
slightly lower than that of the solvent-extracted oils. The contents of free fatty acids (\% as oleic acid) (0.17-0.20) and color (1.2-1.3 r+12-14 y) of the enzyme-extracted $M$. concanensis seed oils were found to be well in line with that of the control $(0.18$, and $1.2 r+14$ y respectively) but significantly lower $(P<0.05)$ than that of the solvent-extracted oil (0.32, and $2.1 r+19$ y respectively).

The results of different oxidation parameters of the control, enzyme-, and solvent-extracted $M$. concanensis seed oils are shown in Table 3 . The specific extinctions at 232 and $270 \mathrm{~nm}$, which revealed the oxidative deterioration and purity of the oils (Anwar et al., 2006a), of enzyme-extracted $M$. concanensis seed oils ranged from 2.88 to 2.94 and 0.57 to 0.62 , respectively. The content of conjugated diene and triene of the enzyme-extracted oils was found to be comparable to that of the control $(2.95$, $0.60)$, but significantly $(P<0.05)$ lower than that of solvent-extracted oil $(3.17,0.67)$. The peroxide and $p$-anisidine values of enzyme-extracted $M$. concanensis seed oil (1.08-1.22 meq/kg and 1.611.65 respectively) were comparable to that of the control (1.24 meq/kg and 1.59 respectively), however, these were significantly $(P<0.05)$ lower than that of the solvent-extracted oil $(1.73 \mathrm{meq} / \mathrm{kg}$ and 1.82 , respectively). A noticeably lower level of the values of different oxidation parameters and thus good oxidative stability exhibited in the present analysis of enzyme-extracted $M$. concanensis seed oil as compared to the solvent-extracted oil might be attributed to the extraction technique applied. The conventional vegetable oil seed extraction process is performed by means of organic solvents, where the high operational temperature might affect the oil quality and its composition, particularly, with regard to the oxidation state. No previously reported data on the oxidation parameters of enzyme-extracted $M$. concanensis seed oil is available with which to compare the results of our present analysis.

Table 4 shows the fatty acid composition of the control, enzyme-, and solvent-extracted $M$. concanensis seed oils. The contents of oleic acid (18:1) and palmitic (16:0) in the aqueous enzymeextracted oils ranged from 68.64 to $68.78 \%$ and 10.83 to $10.91 \%$, respectively. Other prominent fatty acids like; behnic (22:0), arachidic (20:0) and stearic (18:0) acids in aqueous enzyme-extracted oils were 7.39 to $7.48 \%, 3.71$ to $3.83 \%$ and 2.68 to $2.87 \%$ respectively, followed by palmitoleic (16:1), gadoleic (20:1), and linoleic (18:2) acids from 2.50 to $2.57 \%, 1.82$ to $1.90 \%$, and 1.59 to $1.65 \%$, respectively. There was no significant $(P>0.05)$ difference in the amounts of the major fatty acids, except stearic (18:0) and linoleic (18:2) acids in the control, enzyme-, and solventextracted $M$. concanensis seed oils. The results of the present investigation of the fatty acid profiles of $M$. concanensis seed oils are in agreement with those of Abdulkarim et al. (2005) who showed no significant variation in the contents of major fatty acids in the enzyme-, and solvent-extracted $M$. oleifera seed oils.

Table 5 shows the contents of different tocopherols in the control, enzyme-, and solventextracted $M$. concanensis seed oils. The levels of

Table 3

Determination of the oxidative state of Moringa concanensis seed oils ${ }^{A}$

\begin{tabular}{lccccc}
\hline & & \multicolumn{3}{c}{ Enzyme-extracted } & \multirow{2}{*}{ Control } \\
\cline { 3 - 5 } Constituent & Solvent-extracted & Natuzyme & Kemzyme & Feedzyme & \\
\hline Conjugated diene $\varepsilon^{1 \%}{ }^{1 \mathrm{~cm}}(\lambda 232)$ & $3.17 \pm 0.24^{\mathrm{a}}$ & $2.92 \pm 0.22^{\mathrm{b}}$ & $2.88 \pm 0.15^{\mathrm{b}}$ & $2.94 \pm 0.23^{\mathrm{b}}$ & $2.95 \pm 0.19^{\mathrm{b}}$ \\
Conjugated triene $\varepsilon^{1 \%}{ }^{1 \mathrm{~cm}}(\lambda 270)$ & $0.67 \pm 0.02^{\mathrm{a}}$ & $0.59 \pm 0.01^{\mathrm{bc}}$ & $0.62 \pm 0.01^{\mathrm{b}}$ & $0.57 \pm 0.02^{\mathrm{c}}$ & $0.60 \pm 0.01^{\mathrm{bc}}$ \\
Peroxide value (m eq/kg of oil) & $1.73 \pm 0.14^{\mathrm{a}}$ & $1.22 \pm 0.13^{\mathrm{b}}$ & $1.12 \pm 0.09^{\mathrm{c}}$ & $1.08 \pm 0.11^{\mathrm{c}}$ & $1.24 \pm 0.13^{\mathrm{b}}$ \\
$p$-anisidine & $1.82 \pm 0.06^{\mathrm{a}}$ & $1.65 \pm 0.04^{\mathrm{b}}$ & $1.61 \pm 0.08^{\mathrm{b}}$ & $1.62 \pm 0.11^{\mathrm{b}}$ & $1.59 \pm 0.09^{\mathrm{b}}$ \\
\hline
\end{tabular}

${ }^{A}$ Values are means \pm SD, of three Moringa concanensis seed oils analyzed individually in triplicate.

Mean values in the same row followed by the same superscript letters are not significantly different $(P>0.05)$.

Table 4

Fatty acid composition ( $\mathrm{g} / 100 \mathrm{~g})$ of Moringa concanensis seed oils ${ }^{\mathrm{A}}$

\begin{tabular}{cccccc}
\hline & & \multicolumn{3}{c}{ Enzyme-extracted } \\
\cline { 3 - 4 } Fatty Acid & Solvent-extracted & Natuzyme & Kemzyme & Feedzyme & Control \\
\hline $\mathrm{C}_{16: 0}$ & $11.92 \pm 0.21^{\mathrm{a}}$ & $10.88 \pm 0.19^{\mathrm{a}}$ & $10.91 \pm 0.24^{\mathrm{a}}$ & $10.83 \pm 0.17^{\mathrm{a}}$ & $11.20 \pm 0.21^{\mathrm{a}}$ \\
$\mathrm{C}_{16: 1}$ & $2.44 \pm 0.05^{\mathrm{a}}$ & $2.57 \pm 0.06^{\mathrm{a}}$ & $2.53 \pm 0.04^{\mathrm{a}}$ & $2.50 \pm 0.03^{\mathrm{a}}$ & $2.68 \pm 0.07^{\mathrm{a}}$ \\
$\mathrm{C}_{18: 0}$ & $3.64 \pm 0.18^{\mathrm{a}}$ & $2.87 \pm 0.12^{\mathrm{b}}$ & $2.68 \pm 0.14^{\mathrm{b}}$ & $2.84 \pm 0.16^{\mathrm{b}}$ & $2.86 \pm 0.13^{\mathrm{b}}$ \\
$\mathrm{C}_{18: 1}$ & $67.30 \pm 1.72^{\mathrm{a}}$ & $68.72 \pm 1.85^{\mathrm{a}}$ & $68.64 \pm 2.50^{\mathrm{a}}$ & $68.78 \pm 1.95^{\mathrm{a}}$ & $68.07 \pm 2.11^{\mathrm{a}}$ \\
$\mathrm{C}_{18: 2}$ & $1.77 \pm 0.01^{\mathrm{a}}$ & $1.62 \pm 0.02^{\mathrm{bc}}$ & $1.65 \pm 0.02^{\mathrm{bc}}$ & $1.59 \pm 0.01^{\mathrm{c}}$ & $1.70 \pm 0.02^{\mathrm{b}}$ \\
$\mathrm{C}_{20: 0}$ & $3.65 \pm 0.08^{\mathrm{a}}$ & $3.75 \pm 0.11^{\mathrm{a}}$ & $3.83 \pm 0.09^{\mathrm{a}}$ & $3.71 \pm 0.06^{\mathrm{a}}$ & $3.79 \pm 0.07^{\mathrm{a}}$ \\
$\mathrm{C}_{20: 1}$ & $1.79 \pm 0.05^{\mathrm{a}}$ & $1.85 \pm 0.07^{\mathrm{a}}$ & $1.90 \pm 0.09^{\mathrm{a}}$ & $1.82 \pm 0.06^{\mathrm{a}}$ & $1.74 \pm 0.08^{\mathrm{a}}$ \\
$\mathrm{C}_{22: 0}$ & $7.58 \pm 0.18^{\mathrm{a}}$ & $7.48 \pm 0.15^{\mathrm{a}}$ & $7.39 \pm 0.12^{\mathrm{a}}$ & $7.46 \pm 0.14^{\mathrm{a}}$ & $7.34 \pm 0.16^{\mathrm{a}}$ \\
\hline
\end{tabular}

${ }^{A}$ Values are means \pm SD, of three Moringa concanensis seed oils analyzed individually in triplicate.

Mean values in the same row followed by the same superscript letters are not significantly different $(P>0.05)$. 
Table 5

Comparison of tocopherol in Moringa concanensis seed oils ${ }^{\mathrm{A}}$

\begin{tabular}{|c|c|c|c|c|c|}
\hline \multirow[b]{2}{*}{ Tocopherols ( $\mathrm{mg} \mathrm{kg}^{-1}$ ) } & \multirow[b]{2}{*}{ Solvent-extracted } & \multicolumn{3}{|c|}{ Enzyme-extracted } & \multirow[b]{2}{*}{ Control } \\
\hline & & Natuzyme & Kemzyme & Feedzyme & \\
\hline $\begin{array}{l}\alpha \\
\gamma \\
\delta\end{array}$ & $\begin{array}{l}79.40 \pm 2.36^{b} \\
11.38 \pm 0.48^{c} \\
29.61 \pm 1.21^{b}\end{array}$ & $\begin{array}{c}74.29 \pm 2.67^{\mathrm{c}} \\
18.83 \pm 0.56^{\mathrm{ab}} \\
30.50 \pm 1.72^{\mathrm{b}}\end{array}$ & $\begin{array}{l}82.05 \pm 2.49^{a} \\
16.93 \pm 0.75^{b} \\
29.27 \pm 1.18^{b}\end{array}$ & $\begin{array}{l}72.76 \pm 2.71^{\mathrm{c}} \\
21.22 \pm 0.82^{\mathrm{a}} \\
35.49 \pm 1.52^{\mathrm{a}}\end{array}$ & $\begin{array}{l}69.27 \pm 2.10^{c} \\
17.56 \pm 0.53^{b} \\
30.78 \pm 1.34^{b}\end{array}$ \\
\hline
\end{tabular}

${ }^{A}$ Values are means \pm SD, of three Moringa concanensis seed oils analyzed individually in triplicate.

Mean values in the same row followed by the same superscript letters are not significantly different $(P>0.05)$

$\alpha-, \gamma-$, and $\delta$-tocopherol in the enzyme-extracted oils were $72.76-82.05,16.93-21.22$, and 29.27-35.49 $\mathrm{mg} \mathrm{kg}^{-1}$, respectively. The content of $\alpha$-tocopherol, which exhibits the highest vitamin $\mathrm{E}$ activity (Anwar et al., 2006a), in the Kemzyme-extracted oil, was found to be higher, whereas, Feedzyme-, and Natuzye-extracted oils showed significantly $(P<$ $0.05)$ lower values than that of solvent-extracted oil. The concentration of $\delta$-tocopherol, with potent antioxidant activity (Anwar et al., 2006a), in the Natuzyme-, and Kemzyme-extracted oils (30.50 and $29.27 \mathrm{mg} \mathrm{kg}^{-1}$, respectively) was in close agreement with the control, and solvent-extracted oil (30.78 and $29.61 \mathrm{mg} \mathrm{kg}^{-1}$, respectively). However, a significantly $(P<0.05)$ higher content of $\delta$-tocopherol was observed in Feedzyme-extracted oil $\left(35.49 \mathrm{mg} \mathrm{kg}^{-1}\right)$. The level of $\gamma$-tocopherol in enzyme-extracted oils (16.93-21.22 $\mathrm{mg} \mathrm{kg}^{-1}$ ), was significantly higher than that of solvent-extracted (11.38 $\mathrm{mg} \mathrm{kg}^{-1}$ ) oil. In context of $\delta$-tocopherol concentration, Kemzyme-extracted $\left(16.93 \mathrm{mg} \mathrm{kg}^{-1}\right)$ oil was noted to have close resemblance to that of the control $\left(17.56 \mathrm{mg} \mathrm{kg}^{-1}\right)$. No previous reports on the tocopherol contents of enzyme-extracted $M$. concanensis seed oils are available in the literature which with the data of present analysis could be compared.

It could be concluded from the results of the present investigation that aqueous enzymatic treatment enhanced the oil yield of $M$. concanensis seeds with respect to the control although the yield of solvent extraction was not reached. The oil extracted through this approach revealed improved oxidative stability without exhibiting any considerable change in the contents of major fatty acids. Furthermore, the aqueous phase obtained through this extraction method seems to be a potential source of edible protein, and may be utilized for value-addition in beverages and other food commodities.

\section{REFERENCES}

Abdulkarim SM, Long K, Lai OM, Muhammad SKS, Ghazali HM. 2005. Some physico-chemical properties of Moringa oleifera seed oil extracted using solvent and aqueous enzymatic methods. Food Chem. 93, 253-263.

AOAC. 1990. Official Methods of Analysis of the Association of Official Analytical Chemists,
Association of Official Analytical Chemist. 14th Ed., Arlington, VA.

AOCS. 1997. Official and Recommended Practices of the American Oil Chemists Society, American Oil Chemist Society. 5th Ed., AOCS Press, Champaign.

Anwar F, Bhanger, MI. 2003. Analytical characterization of Moringa oleifera seed oil grown in temperate regions of Pakistan, J. Agric. Food Chem. 51, 6558-6563.

Anwar F, Latif S, Ashraf M. 2006a. Analytical characterization of Hemp (Cannabis sativa) seed oil from different agro-ecological zones of Pakistan. J. Am. Oil Chem. Soc. 83, 323-329.

Anwar F, Latif S, Ashraf M, Gilani AH. 2007. Moringa oleifera: a food plant with multiple bio-chemical and medicinal uses-A Review. Phytother. Res. 21, 17-25.

Anwar F, Zafar SN, Rashid U. 2006b. Characterization of Moringa oleifera seed oil from drought and irrigated regions of Punjab, Pakistan. Grasas Y Aceites. 57(2), 160-168.

Aregheore EM. 2002. Intake and digestibility of Moringa oleifera-batiki grass mixtures by rowing goats, Small Rumin. 46, 23-28.

Bhattacharjee P, Singhal RS and Tiwari SR. 2007. Supercritical carbon dioxide extraction of cottonseed oil. J. Food Eng. 79(3), 892-898.

Christensen FM. 1991. Extraction by aqueous enzymatic processes. Inform. 2, 984

Corbett P. 2003. It is time for an oil change! Opportunities for high oleic vegetables oils. Inform. 14, 480-481.

EPA. 2001. National emissions standards for hazardous air pollutants: Solvent extraction for vegetable oil production, Environmental Protection Agency. 40 CFR Part 63, Final rule, Federal register 66:19005-19026.

Hanmoungjai P, Pyle DL, Niranjan K. 2001. Enzymatic process for extracting oil and protein from rice bran. $J$. Am. Oil Chem. Soc. 78, 817-821.

ISO. 1977. Oilseed residue determination of total ash, International Organization for Standardization, Geneva, Standard No.749.

IUPAC. 1987. Standard methods for the analysis of oils, fats and derivatives, International Union of Pure and Applied Chemistry. 7th Rev. Ed., edited by C. Paquot and A. Hautfenne, Blackwell Scientific, London.

Johnson LA, Lusas EW. 1983. Comparison of alternative solvents for oil extraction. J. Am. Oil Chem. Soc. 60(2), 229-242.

Karlovic DJ, Bocevska M, Jakolevic J, Turkulov J. 1994. Corn germ oil extraction by a new enzymatic process. Acta Aliment. 23, 389-400.

Manzoor M, Anwar F, Iqbal T, Bhanger MI. 2007. Physicochemical characterization of Moring concanensis seeds and seed oil. J. Am. Oil Chem. Soc. 84, 413419.

Morimitsu Y, Hayashi K, Nakagama Y, Horio F, Uchida K, Osawa T. 2000. Antiplatelet and anticancer 
isothiocyanates in Japanese horseradish, wasabi. BioFactors 13, 271-276.

Mughal MH, Ali G, Srivastava PS, Iqbal M. 1999. Improvement of drumstick (Moringa pterygosperma Gaertn.) - a unique source of food and medicine through tissue culture. Hamdard Med. 42, 37-42.

Olson ME. 2003. Ontogenetic origins of floral bilateral symmetry in Moringaceae (Brassicales) American Journal of Botany. 90, 49-71.

Rhee KC, Carter CM, Mattil K.F. 1972. Simultaneous recovery of protein and oil from raw peanuts in an aqueous system. J. Food. Sci. 37, 90-93.

Rosenthal A, Pyle DL, Niranjan K. 1996. Aqueous enzymatic process for edible oil extraction. Enzyme Microb. Technol. 19, 402-420.

Rosenthal A, Pyle DL, Niranjan K, Gilmour S, Trinca L. 2001. Combined effect of operational variables and enzyme activity on aqueous enzymatic extraction of oil and protein from soybean. Enzyme Microb. Technol. 28, 499-509.

Sharma A, Khare SK, Gupta MN. 2002. Enzyme-assisted aqueous extraction of peanut oil. J. Am. Oil Chem. Soc. 79, 215-218.

Shi L, Lu J, Jones G, Loretan PA, Hill WA. 1998 Characteristics and composition of peanut oil prepared by an aqueous extraction method. Life Support Biosci. 5, 225-229.

Siddhuraju P, Becker K. 2003. Antioxidant properties of various solvent extracts of total phenolic constituents from three different agro-climatic origins of drumstick tree Moringa oleifera Lam.). J. Agric. Food Chem. 15, 2144-2155.

Sineiro J, Dominguez H, Nunez MJ, Lema JM. 1998. Optimization of the enzymatic treatment during aqueous oil extraction from sunflower seeds. Food Chem. 61, 467-474.

Singh KK, Kumar K. 1999. Ethnotherapeutics of some medicinal plants used as antipyretic agent among the tribals of India. J. Econ. Taxon. Bot. 23, 135-141.

Tsaknis J, Lalas S, Gergis V, Dourtoglou V, Spilitois V. 1999. Characterization of Moringa oleifera variety Mbololo seed oil of Kenya, J. Agric.Food Chem. 47, 4495-4499.

Wrolstad RE. 2003. Analysis of tocopherols and tocotrienols. In Current Protocols in Food Analytical Chemistry (CPFA), Ed. (R.E. Wrolstad), John Wiley \& Sons, UK.

Recibido: 6/8/07 Aceptado: 11/10/07 